\begin{tabular}{|l|l|l|l|l|l|l|}
\hline InterteXto & Uberaba & UFTM & $\begin{array}{l}\text { v. 1 } \\
\text { n. } 2\end{array}$ & p. 62-81 & 2008 - jul. / dez. & ISSN 1981-0601 \\
\hline
\end{tabular}

\title{
UMA MISSA MUITO ESPECIAL
}

\section{A VERY SPECIAL MASS}

\author{
Ozíris Borges Filho ${ }^{1}$ \\ Sidney Barbosa²
}

\section{Resumo}

Neste trabalho, analisamos o conto Machadiano Missa do galo. Para essa análise utilizamos a metodologia da Topoanálise que consiste em verificar os espaços presentes no texto e sua relação com as outras categorias da narrativa bem como os efeitos de sentido produzidos. O que se mostrará é que a espacialidade deste conto é a própria base sobre a qual ele se constrói.

Palavras-chave: Topoanálise; cenário; proxêmica.

\section{Abstract}

In this study, we analyze Machado's short story Missa do galo. In this paper, we use the methodology of Topoanalysis witch consists in the examination of the spaces in the text and its relationship to other categories of narrative and the effects of meaning produced. We are going to show that the spatiality of this short story is the very basis on which it is built.

Key-words: Topoanalysis; scenery; proxemics.

\section{Introdução}

Neste texto, analisaremos o conto machadiano Missa do galo. Ele foi publicado pela primeira vez em 1894 em A Semana, depois incluído no livro de contos Páginas recolhidas, 1899. Para esta análise, utilizaremos a versão do conto publicada pela editora Ática e que se encontra nas referências.

O conto trata das recordações de Nogueira sobre uma noite em que haveria uma missa do galo. Ele narra o episódio que se passou entre ele e Conceição, esposa do Meneses, quando tinha 17 anos.

Para essa análise, utilizaremos a perspectiva da Topoanálise que foi desenvolvida a partir das idéias de Bachelard, luri Lotman, Osman Lins dentre outros. A intenção é mostrar as estratégias utilizadas pelo narrador na

\footnotetext{
${ }^{1}$ Professor na UFTM - Universidade Federal do Triângulo Mineiro.

${ }^{2}$ Professor da UNESP - campus de Araraquara.
} 


\begin{tabular}{|l|l|l|l|l|l|l|}
\hline InterteXto & Uberaba & UFTM & $\begin{array}{l}\text { v. 1 } \\
\text { n. } 2\end{array}$ & p. 62-81 & 2008 - jul. / dez. & ISSN 1981-0601 \\
\hline
\end{tabular}

representação do espaço no enredo bem como verificar os diversos efeitos de sentido produzidos.

\section{Percurso espacial}

Para a Topoanálise, o percurso espacial é formado pelo encadeamento dos espaços presentes na obra. Desse ponto de vista, o enredo pode ser classificado em monotópico, se se passa em apenas um espaço, ou politópico, se ocorre em mais de um.

No caso deste conto machadiano, temos um enredo politópico já que a trama ocorre na casa do Meneses, mas dois outros espaços também são mencionados: a rua e a igreja. No entanto, é interessante notar que os espaços da rua e da igreja aparecem apenas no final, formando uma pequena fratura, por assim dizer, no enredo. É que a cena principal se passa quase integralmente na "sala da frente daquela casa assobradada". Isso ocorre até quase à meia noite, quando Nogueira sai para a missa. Chegando lá, há apenas uma breve referência à igreja e ao estado emocional da personagem narradora. Após isso, o narrador menciona que encontrou Conceição no outro dia e que ela se comportava como se nada acontecera na véspera. Portanto, o espaço inicial e final do enredo são os mesmos. Entre o momento inicial e o final há um pequeno interstício espacial que marca a estada de Nogueira na igreja, assistindo à missa do galo.

Note-se também que entre os dois únicos tipos de espaço que podem existir, a saber, cenário e natureza, neste conto encontramos apenas cenários, isto é, espaços construídos pelo homem.

Também para a Topoanálise, há basicamente três maneiras de representação do espaço na obra literária: a realista, a imaginosa e a fantasista. No primeiro caso, o narrador toma por base espaços realmente existente no contexto extratextual. Ele cita lugares existentes o que provoca um forte efeito de realidade. No segundo, os espaços citados no texto são 


\begin{tabular}{|l|l|l|l|l|l|l|}
\hline InterteXto & Uberaba & UFTM & $\begin{array}{l}\text { v. 1 } \\
\text { n. } 2\end{array}$ & p. 62-81 & 2008 - jul. / dez. & ISSN 1981-0601 \\
\hline
\end{tabular}

inventados, mas guardam semelhança com espaços reais. Por último, aparecem espaços que não seguem as regras do mundo real.

Assim, podemos afirmar que no conto machadiano os dois espaços são realistas, na medida em que o narrador cita lugares realmente existentes no Rio de Janeiro na época em que o conto foi publicado e até hoje como é o caso da Rua do Senado.

\section{O espaço da narração e o espaço da narrativa}

Antes de analisarmos os dois espaços presentes no conto, a casa e a igreja, é importante salientarmos a diferença que a topoanálise apresenta entre o espaço da narrativa e o espaço da narração.

Narrativa e narração são palavras polissêmicas como bem assinalam Reis e Lopes (1988, p. 58). Portanto, é imprescindível esclarecermos aqui qual a acepção dessas palavras que são empregadas por nós. Por narrativa entendemos o enredo. Por narração, o ato de narrar. Dessa maneira, há uma questão bastante interessante que é posta pela Topoanálise que é o fato de 0 espaço da narração nem sempre coincidir com o espaço da narrativa. Tal é o caso de Missa do galo. No primeiro parágrafo, o narrador homo e extradiegético afirma o seguinte:

Nunca pude entender a conversação que tive com uma senhora, há muitos anos, contava eu dezessete, ela trinta. Era noite de Natal. Havendo ajustado com um vizinho irmos à missa do galo, preferi não dormir; combinei que eu iria acordálo à meia-noite. (p. 81)

Como se pode observar, o enredo aconteceu há muitos anos, portanto o tempo da narração é diferente do tempo da narrativa. Isso também ocorre com o espaço. O espaço da narração, neste conto, não é explicitado. No entanto, como o espaço da narrativa acontece na casa de Meneses e como o narrador afirma, no final da narrativa, que nunca mais voltou àquela casa, conclui-se que, assim como o tempo, os dois espaços são diferentes. 


\begin{tabular}{|l|l|l|l|l|l|l|}
\hline InterteXto & Uberaba & UFTM & $\begin{array}{l}\text { v. 1 } \\
\text { n. } 2\end{array}$ & p. 62-81 & 2008 - jul. / dez. & ISSN 1981-0601 \\
\hline
\end{tabular}

Quando tornei ao Rio de Janeiro, em março, o escrivão tinha morrido de apoplexia. Conceição morava no Engenho Novo, mas nem a visitei nem a encontrei. Ouvi mais tarde que casara com o escrevente juramentado do marido. (p. 85)

Como se vê, após a morte do marido, Conceição nem mais morava na antiga casa. Neste conto especificamente o espaço da narração não aparece, mas pode acontecer de o mesmo aparecer com gradações diferenciadas (Cf. Borges Filho, 2007b).

\section{A casa, a rua e a igreja}

A casa em que eu estava hospedado era a do escrivão Meneses, que fora casado, em primeiras núpcias, com uma de minhas primas. A segunda mulher, Conceição, e a mãe desta acolheram-me bem, quando vim de Mangaratiba para o Rio de Janeiro, meses antes, a estudar preparatórios. Vivia tranqüilo, naquela casa assobradada da Rua do Senado, com os meus livros, poucas relações, alguns passeios. (p. 81)

Logo no segundo parágrafo do conto, o narrador homo e autodiegético localiza o enredo. Convém notar o deslocamento espacial efetuado pelo protagonista: Mangaratiba $\rightarrow$ Rio de Janeiro. Esse deslocamento mais os passeios referenciados no trecho e ainda a ida à missa mostra que se trata de um personagem que se move para vários lugares, portanto, do ponto de vista espacial, temos uma personagem politópica, isto é, personagem que transita por vários espaços além daquele que é o seu próprio. Esse primeiro deslocamento da personagem que sai do interior do estado para a capital com o objetivo de estudar também cumpre a função de a situar socialmente. Com efeito, na época em que se passa o conto, 1861-1862 como se afirma durante a narrativa, apenas as famílias mais abastadas podiam enviar seus filhos para estudarem na capital.

Ainda no parágrafo acima transcrito, é importante notar a caracterização e localização da casa. Com relação à caracterização, percebemos que se trata de uma casa "vertical", ou seja, uma casa com mais de um andar. Temos o 


\begin{tabular}{|l|l|l|l|l|l|l|}
\hline InterteXto & Uberaba & UFTM & $\begin{array}{l}\text { v. 1 } \\
\text { n. } 2\end{array}$ & p. 62-81 & 2008 - jul. / dez. & ISSN 1981-0601 \\
\hline
\end{tabular}

térreo e o segundo pavimento que poderíamos chamar de sótão em qualquer um dos dois sentidos que encontramos no Dicionário Houaiss "parte da casa entre o forro e o telhado; desvão [Geralmente é usado como depósito de coisas fora de uso, mas às vezes também se usa como habitação ou dormitório.]; último andar de um edifício".

Já a localização, Rua do Senado, coloca a casa em um dado referencial do mundo externo já que essa rua realmente existiu na época em que se passa o conto. Essa citação de lugares existentes, comum na fiç̧ão de Machado, provoca um efeito de sentido de realidade ou referente. É o efeito de real de que fala Barthes.

Após esse primeiro parágrafo com referência social seguem outros em que o narrador caracteriza Meneses, o marido de Conceição, e esta última. Sobre Meneses, que era escrivão, o narrador também nos informa que ele possuía uma amante e que se encontrava com ela uma vez por semana. Essa saída de Meneses ocorrera naquela véspera de natal em que o protagonista aguarda a missa do galo.

Já a caracterização de Conceição é mais abundante, o que é natural já que essa personagem desempenha um papel fundamental na estrutura do conto narrado. O que mais marca essa caracterização da personagem é a ambigüidade, a possibilidade do duplo:

Boa Conceição! Chamavam-lhe "a santa", e fazia jus ao título, tão facilmente suportava os esquecimentos do marido. Em verdade, era um temperamento moderado, sem extremos, nem grandes lágrimas, nem grandes risos. No capítulo de que trato, dava para maometana; aceitaria um harém, com as aparências salvas. Deus me perdoe, se a julgo mal. Tudo nela era atenuado e passivo. O próprio rosto era mediano, nem bonito nem feio. Era o que chamamos uma pessoa simpática. Não dizia mal de ninguém, perdoava tudo. Não sabia odiar; pode ser até que não soubesse amar. (p. 81, grifos nossos)

Observa-se que a caracterização deixa dúbia a figura, inclusive física, de Conceição. Esse tema é reforçado pela presença em dois momentos da 


\begin{tabular}{|l|l|l|l|l|l|l|}
\hline InterteXto & Uberaba & UFTM & $\begin{array}{l}\text { v. 1 } \\
\text { n. } 2\end{array}$ & p. 62-81 & 2008 - jul. / dez. & ISSN 1981-0601 \\
\hline
\end{tabular}

conjunção alternativa "nem... nem". Essa caracterização, claro, não é gratuita e ela continua em outros momentos. Essa apresentação ambígua da personagem contribui para a atmosfera dúbia do texto. É por isso que o narrador afirma no início do texto que "Nunca pude entender a conversação que tive com uma senhora, há muitos anos, contava eu dezessete, ela trinta." Essa dúvida está relacionada à atmosfera de que falamos anteriormente e que se liga desde o primeiro momento à construção dessa personagem, Conceição.

Em seguida, encontramos o seguinte parágrafo:

Naquela noite de Natal foi o escrivão ao teatro. Era pelos anos de 1861 ou 1862. Eu já devia estar em Mangaratiba, em férias; mas fiquei até o Natal para ver "a missa do galo na corte". A família recolheu-se à hora do costume; eu meti-me na sala da frente, vestido e pronto. Dali passaria ao corredor da entrada e sairia sem acordar ninguém. Tinha três chaves a porta; uma estava com o escrivão, eu levaria outra, a terceira ficava em casa. (p. 81)

Os dois primeiros períodos marcam a temporalidade da narrativa: noite de natal e 1861 ou 1862. Após a explicação do porquê se encontrava ainda no Rio de Janeiro, o narrador nos dá informações preciosas de seu topos. Todos já tinham se recolhido, portanto ele estava só "na sala da frente". A locução "da frente" remete-nos à coordenada espacial da frontalidade: diante $X$ atrás. Tal posicionamento, pelas informações textuais, se deve à facilidade de 0 protagonista sair da casa "sem acordar ninguém".

Esse trecho, pode-se dizer, é a preparação para o acontecimento dramático de que trata o narrador. Então, além da coordenada da frontalidade, há outra que se instaura no evento que se seguirá: a da interioridade: interior $X$ exterior. Todo o acontecimento que será narrado a seguir se passa dentro da casa por oposição ao exterior. Essa espacialidade homologa a cena que ocorrerá entre Nogueira e Conceição na medida em que se trata de ações íntimas ou reservadas.

Outra relação espacial interessante que podemos perceber no trecho é que, entre todos os outros cômodos da casa, a principal cena se passará 


\begin{tabular}{|l|l|l|l|l|l|l|}
\hline InterteXto & Uberaba & UFTM & $\begin{array}{l}\text { v. 1 } \\
\text { n. } 2\end{array}$ & p. 62-81 & 2008 - jul. / dez. & ISSN 1981-0601 \\
\hline
\end{tabular}

naquela sala. Portanto, há uma relação de englobante $X$ englobado nesses espaços. A casa é o espaço maior, englobante, e a sala é o espaço menor, englobado. Essa relação reforça um dos principais pressupostos da estrutura do conto no século XIX, a unidade de espaço. A sala então é um espaço restrito, fechado e isotrópico, ou seja, suas propriedades físicas são invariáveis. Passemos então há outro parágrafo.

Tinha comigo um romance, os Três mosqueteiros, velha tradução creio do Jornal do Comércio. Sentei-me à mesa que havia no centro da sala, e à luz de um candeeiro de querosene, enquanto a casa dormia, trepei ainda uma vez ao cavalo magro de D'Artagnan e fui-me às aventuras. Dentro em pouco estava completamente ébrio de Dumas. Os minutos voavam, ao contrário do que costumam fazer, quando são de espera; ouvi bater onze horas, mas quase sem dar por elas, um acaso. ( $p$. 81-82)

Além da citação de Dumas, mais uma vez temos uma referência à sala em que se encontra o protagonista e também à localização da personagem. Ela se senta à mesa no centro da sala. A centralidade da personagem é um dado interessante e que irá propiciar a ação de Conceição. Outro dado interessante em relação a essa sala é a percepção que dela nos dá a personagem. Quando se fala em percepção no âmbito da Topoanálise, estamos falando dos gradientes sensoriais, isto é, do aparelho perceptor humano: visão, audição, tato, olfato e paladar. Nogueira, em sua percepção do espaço, utiliza dois sentidos: a visão e a audição. Através da figura do "candeeiro de querosene" infere-se que havia pouca luz no espaço ocupado pela personagem. Ora, pouca luz nos remete a uma percepção limitada do que ocorre em volta, portanto esse detalhe corrobora a dúvida que há no narrador muitos anos depois do ocorrido. Como se vê o espaço está intimamente ligado ao efeito epistemológico provocado no narrador e ao efeito estético provocado no leitor virtual: quais seriam, afinal, as intenções de Conceição naquela noite?

O outro gradiente sensorial presente é o da audição. Quando o narrador nos informa, através de uma bela metonímia, que a "casa dormia" pressupõe- 


\begin{tabular}{|l|l|l|l|l|l|l|}
\hline InterteXto & Uberaba & UFTM & $\begin{array}{l}\text { v. 1 } \\
\text { n. } 2\end{array}$ & p. 62-81 & 2008 - jul. / dez. & ISSN 1981-0601 \\
\hline
\end{tabular}

se que aquele espaço estava carregado de silêncio. Além disso, dada a concentração do narrador em sua leitura, o som do relógio, marcação temporal, quase não é ouvida. Portanto, temos um espaço pouco iluminado e silencioso. Nesse primeiro momento, essa espacialidade propicia a atividade de leitura do protagonista, mas que também possibilitará as ações de Conceição. Àquele trecho citado, segue-se este outro:

Entretanto, um pequeno rumor que ouvi dentro veio acordar-me da leitura. Eram uns passos no corredor que ia da sala de visitas à de jantar; levantei a cabeça; logo depois vi assomar à porta da sala o vulto de Conceição. (p. 82)

Novamente vemos a presença do gradiente sensorial da audição. É através dele que o narrador percebe "um pequeno rumor" provocado pelo deslocamento de Conceição pelo eixo da prospectividade que assume os valores do "perto X longe ou aqui X lá". Nesse sentido, Conceição, que estava ausente, que ocupava o espaço do longe/lá, na perspectiva de Nogueira, agora se aproxima do perto/aqui. Entre o lá e o aqui há um espaço de transição, de ligação que é a figura do corredor, ligando a sala de visitas à de jantar. E é esse deslocamento pelo eixo da verticalidade que será o responsável por toda a tensão deste conto.

Conceição entrou na sala, arrastando as chinelinhas da alcova. Vestia um roupão branco, mal-apanhado na cintura. Sendo magra, tinha um ar de visão romântica, não disparatada com o meu livro de aventuras. Fechei o livro; ela foi sentar-se na cadeira que ficava defronte de mim, perto do canapé. Como eu lhe perguntasse se a havia acordado, sem querer, fazendo barulho, respondeu com presteza:

— Não! qual! Acordei por acordar. (p. 82)

No trecho acima, percebe-se a origem e o fim daquele deslocamento pelo eixo da horizontalidade feito por Conceição. Como ponto de partida, temos a alcova, e como ponto de chegada a sala e mais especificamente a cadeira que ficava em frente a Nogueira. É interessante notar a descrição direta feita 


\begin{tabular}{|l|l|l|l|l|l|l|}
\hline InterteXto & Uberaba & UFTM & $\begin{array}{l}\text { v. 1 } \\
\text { n. } 2\end{array}$ & p. 62-81 & 2008 - jul. / dez. & ISSN 1981-0601 \\
\hline
\end{tabular}

pelo narrador, caracterizando Conceição. As figuras "roupão branco" e "visão romântica" reforçam aquelas características de ambigüidade dada a Conceição anteriormente, intensificando a atmosfera ambígua que povoa o enredo desde o início.

Outro ponto espacial que cumpre destacar no texto é a presença do eixo da frontalidade: diante $X$ atrás. Nesse caso, Conceição ocupa um espaço em frente ao narrador. Esse posicionamento, "defronte", possui vários sentidos, inclusive opostos. Pode significar uma posição de enfrentamento, combate ou pode indicar uma postura de observação e interesse em relação ao objeto visado. Neste caso, pela seqüência narrativa, fica explícito que se trata do segundo sentido. Além disso, quando o narrador situa a personagem feminina, ele acrescenta um outro detalhe daquela sala: o canapé. Note-se que a descrição é feita pelo narrador, mas o espaço e seus objetos vão aparecendo na medida das ações de Conceição: "ela foi sentar-se na cadeira que ficava defronte de mim, perto do canapé". Esse tipo de instauração do espaço é chamado pela Topoanálise de espacialização dissimulada. Esse tipo de espacialização é bastante interessante por não provocar "paradas" dentro da narrativa, isto é, não temos blocos descritivos do espaço para depois situar as personagens e suas ações. Espaço e ação são justapostos um seguindo o outro, um aparecendo pelo outro. Essa estratégia é uma conquista da narrativa moderna, mas que já estava presente em Machado.

Na seqüência narrativa, temos o seguinte parágrafo:

Fitei-a um pouco e duvidei da afirmativa. Os olhos não eram de pessoa que acabasse de dormir; pareciam não ter ainda pegado no sono. Essa observação, porém, que valeria alguma coisa em outro espírito, depressa a botei fora, sem advertir que talvez não dormisse justamente por minha causa, e mentisse para me não afligir ou aborrecer. Já disse que ela era boa, muito boa. (p. 82)

É interessante notar nesse trecho como a dúvida que impera no narrador é também passada sutilmente pela construção sintática. O narrador fala e, logo 


\begin{tabular}{|l|l|l|l|l|l|l|}
\hline InterteXto & Uberaba & UFTM & $\begin{array}{l}\text { v. 1 } \\
\text { n. } 2\end{array}$ & p. 62-81 & 2008 - jul. / dez. & ISSN 1981-0601 \\
\hline
\end{tabular}

depois, recua. No início ele diz que a afirmação de Conceição poderia significar algo, mas esse algo que poderia ser as intenções para com o narrador são logo recusadas no período seguinte, alegando que o motivo seria o de estar ele acordado.

Vejamos o parágrafo seguinte:

Conceição ouvia-me com a cabeça reclinada no espaldar, enfiando os olhos por entre as pálpebras meio-cerradas, sem os tirar de mim. De vez em quando passava a língua pelos beiços, para umedecê-los. Quando acabei de falar, não me disse nada; ficamos assim alguns segundos. Em seguida, vi-a endireitar a cabeça, cruzar os dedos e sobre eles pousar o queixo, tendo os cotovelos nos braços da cadeira, tudo sem desviar de mim os grandes olhos espertos. (p. 82)

Outro ponto interessante da topoanálise refere-se aos espaços pessoais ou proxêmica, isto é, as distâncias em que as personagens se posicionam em relação a outras ou em relação a objetos. A proximidade ocupada por Conceição poderia ser classificada como uma distância social, isto é, uma distância de convivência que se assume no cotidiano ao tratarmos com pessoas conhecidas, mas não íntimas. No entanto, cumpre destacar que a gestualidade da personagem parece contrariar a distância social. Fixar com olhos semi-cerrados, passar a língua pelos lábios algumas vezes e depois pousar o queixo nas mãos e continuar a olhar fixamente o narrador parece indícios fortíssimos de interesse no outro, em Nogueira. Essa é uma das passagens mais fortes e que contribui certamente para a dúvida do narrador anos depois.

Conceição desloca-se mais uma vez.

De costume tinha os gestos demorados e as atitudes tranqüilas; agora, porém, ergueu-se rapidamente, passou para o outro lado da sala e deu alguns passos, entre a janela da rua e a porta do gabinete do marido. Assim, com o desalinho honesto que trazia, dava-me uma impressão singular. Magra embora, tinha não sei que balanço no andar, como quem lhe custa levar o corpo; essa feição nunca me pareceu tão distinta como naquela noite. Parava algumas vezes, examinando um 


\begin{tabular}{|l|l|l|l|l|l|l|}
\hline InterteXto & Uberaba & UFTM & $\begin{array}{l}\text { v. 1 } \\
\text { n. } 2\end{array}$ & p. 62-81 & 2008 - jul. / dez. & ISSN 1981-0601 \\
\hline
\end{tabular}

trecho de cortina ou concertando a posição de algum objeto no aparador; afinal deteve-se, ante mim, com a mesa de permeio. (p. 83)

Esse novo deslocamento provoca uma impressão não usual no narrador. Ele a vê diferentemente, mais ágil e talvez mais bonita. Conceição pára várias vezes, mexendo nos objetos que povoam aquele topos da sala. Seriam indícios de dúvidas? Seriam paradas "estratégicas" para se aproximar mais de Nogueira? O texto não deixa claro, mas o deslocamento de Conceição e sua última parada a deixa mais perto do narrador. A distância entre os protagonistas agora é menor.

O que se observa aqui é a importância da análise das distâncias pessoais para a estruturação da narrativa. Essa proxêmica deve ser analisada tanto em relação a outros sujeitos quanto em relação a objetos. Em algumas narrativas essa importância pode ser menor, mas para esta que aqui está em foco, é importantíssima. Dizemos mais, para este conto a distância interpessoal é o fundamento de todo o conto. Grande parte do efeito estético alcançado pelo conto se situa no nível do deslocamento efetuado por Conceição e seu posicionamento em relação a Nogueira.

Depois de parar em frente a Nogueira, tendo apenas a mesa entre eles, Conceição desloca-se novamente.

Pouco a pouco, tinha-se inclinado; fincara os cotovelos no mármore da mesa e metera o rosto entre as mãos espalmadas. Não estando abotoadas, as mangas, caíram naturalmente, e eu vi-lhe metade dos braços, muito claros, e menos magros do que se poderiam supor. A vista não era nova para mim, posto também não fosse comum; naquele momento, porém, a impressão que tive foi grande. As veias eram tão azuis, que apesar da pouca claridade, podia contá-las do meu lugar. ( $p$. 83)

Porém, o deslocamento que aqui se observa não é o produzido pelo andar. A aproximação entre as personagens se dá pela inclinação de Conceição que assume a mesma posição anterior quando estava na cadeira. A 


\begin{tabular}{|l|l|l|l|l|l|l|}
\hline InterteXto & Uberaba & UFTM & $\begin{array}{l}\text { v. 1 } \\
\text { n. } 2\end{array}$ & p. 62-81 & 2008 - jul. / dez. & ISSN 1981-0601 \\
\hline
\end{tabular}

proximidade fica patente pelo gradiente sensorial da visão. O narrador afirma que, apesar da escassa luminosidade, ele poderia contar a veias dos braços de Conceição. Se antes essa personagem estava situada numa distância social agora se trata de uma distância pessoal. Nessa distância, o campo visual é mais nítido e o outro (objeto ou sujeito) pode ser agarrado. Esse posicionamento provoca outra grande impressão no narrador. Essa impressão é revelada no restante do trecho citado quando o narrador admite que continuava a falar sem se preocupar com a coerência do que dizia.

A presença de Conceição espertara-me ainda mais que o livro. Continuei a dizer o que pensava das festas da roça e da cidade, e de outras coisas que me iam vindo à boca. Falava emendando os assuntos, sem saber por quê, variando deles ou tornando aos primeiros, e rindo para fazê-la sorrir e ver-lhe os dentes que luziam de brancos, todos iguaizinhos. Os olhos dela não eram bem negros, mas escuros; o nariz, seco e longo, um tantinho curvo, dava-lhe ao rosto um ar interrogativo. Quando eu alteava um pouco a voz, ela reprimia-me:

— Mais baixo! mamãe pode acordar. (p. 83)

Nogueira nos descreve outras partes físicas de Conceição o que atesta a proximidade entre os protagonistas. Também a preocupação de não acordar a mãe parece revelar suas intenções, mas nada fica muito explícito. No próximo trecho, fica clara a proximidade entre as personagens.

E não saía daquela posição, que me enchia de gosto, tão perto
ficavam as nossas caras. Realmente, não era preciso falar alto
para ser ouvido: cochichávamos os dois, eu mais que ela,
porque falava mais; ela, às vezes, ficava séria, muito séria,
com a testa um pouco franzida. (p. 83 )

Fica patente a proximidade entre as personagens: "tão perto ficavam as nossas caras." Outro dado dessa distância é o fato de ambos estarem a cochichar. No entanto, aquilo que parecia certeza, novamente é posto em dúvida. Se Conceição possuía a intenção de seduzir Nogueira por que aquela mudança para a seriedade? "ficava séria, muito séria..." Assim, afirmando e 


\begin{tabular}{|l|l|l|l|l|l|l|}
\hline InterteXto & Uberaba & UFTM & $\begin{array}{l}\text { v. 1 } \\
\text { n. } 2\end{array}$ & p. 62-81 & 2008 - jul. / dez. & ISSN 1981-0601 \\
\hline
\end{tabular}

negando, a narrativa vai construindo sua trama, propondo dúvidas ao narrador e enredando o leitor virtual.

Afinal, cansou; trocou de atitude e de lugar. Deu volta à mesa e veio sentar-se do meu lado, no canapé. Voltei-me, e pude ver, a furto, o bico das chinelas; mas foi só o tempo que ela gastou em sentar-se, o roupão era comprido e cobriu-as logo. Recordo-me que eram pretas. Conceição disse baixinho:

- Mamãe está longe, mas tem o sono muito leve; se acordasse agora, coitada, tão cedo não pegava no sono.

- Eu também sou assim.

- O quê? perguntou ela inclinando o corpo para ouvir melhor. (p. 83-84)

Aquela seriedade não é reforçada pelo novo deslocamento da personagem. Conceição agora se senta ao lado do narrador sem nenhum objeto que se interponha entre eles. Dentro da narrativa, essa é a primeira vez que isso acontece. Portanto, a aproximação entre as personagens vai aumentando gradativamente.

Outro ponto interessante do excerto acima transcrito refere-se à primeira fala de Conceição: “Mamãe está longe...". Aquela preocupação com a mãe continua. A narrativa continua insinuando os desejos de Conceição. Mas o que nos chama a atenção é o advérbio "longe" que nos mostra uma inversão no posicionamento das personagens pelo eixo da prospectividade. No início do deslocamento da personagem uma delas se situa no aqui/perto, enquanto a outra se situa no lá/longe. Nesse momento da narrativa essa oposição entre as personagens, do ponto de vista do espaço, desaparece. Ambos ocupam o espaço do aqui/perto e uma outra personagem, a mãe de Conceição, ocupa o espaço do lá/longe. Esse é mais um índice que reforça a distância interpessoal dos protagonistas. Distância alterada pela nova inclinação feita pela personagem ao final do excerto. 


\begin{tabular}{|l|l|l|l|l|l|l|}
\hline InterteXto & Uberaba & UFTM & $\begin{array}{l}\text { v. 1 } \\
\text { n. } 2\end{array}$ & p. 62-81 & 2008 - jul. / dez. & ISSN 1981-0601 \\
\hline
\end{tabular}

Fui sentar-me na cadeira que ficava ao lado do canapé e repeti a palavra. Riu-se da coincidência; também ela tinha o sono leve; éramos três sonos leves. (p. 84)

Para além do fato de a distância ser alterada ainda mais como provam as informações nesse parágrafo, deve-se destacar que essa é a primeira vez que o narrador toma uma atitude. Até esse ponto da narrativa, Conceição tomava todas as atitudes enquanto o narrador se mostrava passivo. Esse fato muda nesse parágrafo.

Há impressões dessa noite, que me aparecem truncadas ou confusas. Contradigo-me, atrapalho-me. Uma das que ainda tenho frescas é que, em certa ocasião, ela, que era apenas simpática, ficou linda, ficou lindíssima. Estava de pé, os braços cruzados; eu, em respeito a ela, quis levantar-me; não consentiu, pôs uma das mãos no meu ombro, e obrigou-me a estar sentado. Cuidei que ia dizer alguma coisa; mas estremeceu, como se tivesse um arrepio de frio, voltou as costas e foi sentar-se na cadeira, onde me achara lendo. ( $p$. 84)

Mais uma vez o narrador contribui para a atmosfera de ambigüidade, de incerteza que cerca a narrativa. Ele próprio reconhece que as lembranças daquela noite de Natal não estão claras.

É interessante notar que há uma mudança espacial entre as personagens. Antes, ambos se situavam no eixo da horizontalidade, agora, há um deslocamento no eixo da verticalidade. Conceição se posiciona em pé, acima de Nogueira e o força a permanecer sentado. Enquanto Conceição se situa no alto, o narrador se situa no baixo. Essa espacialidade ratifica a qualidade de "ser ativo" de Conceição, ela é que toma as iniciativas. Mais uma vez ela manifesta essa característica e também esse é o ponto de proximidade máxima a que chegarão as personagens neste conto. É o que revela o toque de mão de Conceição. Do ponto de vista dessa distância interpessoal de que falamos, temos nesse trecho o clímax do conto. Além disso, parece-nos que este também é o clímax da dubiedade do conto. Se Conceição realmente queria algo com o narrador esse foi o momento em que algo poderia ter 


\begin{tabular}{|l|l|l|l|l|l|l|}
\hline InterteXto & Uberaba & UFTM & $\begin{array}{l}\text { v. 1 } \\
\text { n. } 2\end{array}$ & p. 62-81 & 2008 - jul. / dez. & ISSN 1981-0601 \\
\hline
\end{tabular}

acontecido. Esse clímax, cremos, é indiciado pelo estremecimento de Conceição.

Após esse momento máximo de conjunção entre as personagens acontece uma disjunção. Da proximidade maior começa um distanciamento, da tensão maior passa-se para uma distensão. Do interesse possível, passa-se agora ao desinteresse explícito. Isso fica claro quando Conceição vira as costas para Nogueira e vai sentar-se no lugar que ele antes ocupara. Há como que uma permuta espacial entre os protagonistas.

Essa passagem para o desfecho, saindo do clímax fica claro numa passagem que aparece alguns parágrafos adiante.

Já agora não trocava de lugar, como a princípio, e quase não saíra da mesma atitude. Não tinha os grandes olhos compridos, e entrou a olhar à toa para as paredes.

- Precisamos mudar o papel da sala, disse daí a pouco, como se falasse consigo. (p. 85)

Fica claro o desinteresse total da personagem feminina, manifestado espacialmente pela postura rígida e parada que assumiu. Aquela movimentação do início, cedeu lugar à estaticidade. O próprio narrador já não a vê da mesma maneira que anteriormente, daí dizer que Conceição já não possuía os "grandes olhos compridos". A personagem chega ao ponto de falar consigo mesma como se não houvesse ninguém mais na sala. Atitude bem diferente de quando pela primeira vez adentrou a sala e não tirava os olhos do narrador.

Em termos de caracterização da sala, há uma passagem bastante interessante. 


\begin{tabular}{|l|l|l|l|l|l|l|}
\hline InterteXto & Uberaba & UFTM & $\begin{array}{l}\text { v. 1 } \\
\text { n. } 2\end{array}$ & p. 62-81 & 2008 - jul. / dez. & ISSN 1981-0601 \\
\hline
\end{tabular}

Dali relanceou a vista pelo espelho, que ficava por cima do canapé, falou de duas gravuras que pendiam da parede.

- Estes quadros estão ficando velhos. Já pedi a Chiquinho para comprar outros.

Chiquinho era o marido. Os quadros falavam do principal negócio deste homem. Um representava "Cleópatra"; não me recordo o assunto do outro, mas eram mulheres. Vulgares ambos; naquele tempo não me pareciam feios. (p. 84)

Após deixar o narrador sentado na cadeira ao lado do canapé e ir sentar-se onde antes estivera Nogueira, Conceição faz alusão a dois quadros pendurados na parede. Segundo o narrador, esses objetos qualificam o espaço em que morava Meneses. Uma das funções do espaço na obra literária é justamente essa: a de caracterizar social e ideologicamente a personagem que nele vive. Segundo o narrador, é essa função que podemos depreender mais explicitamente. No entanto, furtivamente, dissimuladamente, podemos levantar a hipótese de que esse dado espacial também reflete, também caracteriza Conceição. Em outras palavras, Cleópatra foi igualmente célebre por sua vida promíscua, por sua infidelidade. Talvez o quadro também simbolize o desejo de Conceição de trair o marido, talvez esse seja o real motivo de ela não gostar dos quadros. O livro Os três mosqueteiros também pode ser tomado por esse viés, cremos. Lembre-se de que nesse romance, há uma mulher que trai seu marido. Trata-se da Condessa de Winter, esposa do mosqueteiro Athos.

- São bonitos, disse eu.

- Bonitos são; mas estão manchados. E depois francamente, eu preferia duas imagens, duas santas. Estas são mais próprias para sala de rapaz ou de barbeiro.

- De barbeiro? A senhora nunca foi a casa de barbeiro.

- Mas imagino que os fregueses, enquanto esperam, falam de moças e namoros, e naturalmente o dono da casa alegra a vista deles com figuras bonitas. Em casa de família é que não acho próprio. É o que eu penso; mas eu penso muita coisa assim esquisita. Seja o que for, não gosto dos quadros. Eu tenho uma Nossa Senhora da Conceição, minha madrinha, muito bonita; mas é de escultura, não se pode pôr na parede, nem eu quero. Está no meu oratório. (p. 84)

O que nos chama atenção nesse trecho é uma discussão em relação a dois espaços: o do barbeiro e o da casa de família. Na concepção de 


\begin{tabular}{|l|l|l|l|l|l|l|}
\hline InterteXto & Uberaba & UFTM & $\begin{array}{l}\text { v. 1 } \\
\text { n. } 2\end{array}$ & p. 62-81 & 2008 - jul. / dez. & ISSN 1981-0601 \\
\hline
\end{tabular}

Conceição, os quadros não poderiam fazer parte de uma casa de família por serem impróprios. Ela prefere o quadro de uma santa. Tal fato reforça a caracterização da personagem como uma pessoa ligada à religião, fato, aliás, que o próprio nome já indicia.

Queria e não queria acabar a conversação; fazia esforço para arredar os olhos dela, e arredava-os por um sentimento de respeito; mas a idéia de parecer que era aborrecimento, quando não era, levava-me os olhos outra vez para Conceição. A conversa ia morrendo. Na rua, o silêncio era completo. ( $p$. 85)

Já chegando ao fim da narrativa, vemos a primeira intervenção do espaço de fora. Instala-se explicitamente a coordenada espacial da interioridade: interior $X$ exterior. $O$ espaço exterior figurativizado pela rua tematiza o silêncio, o mesmo que ia tomando conta também do interior: "A conversa ia morrendo." Esse silêncio que passa a ser predominante dentro e fora já evidencia, outrossim, o desfecho da narrativa e homogeneiza os dois espaços. É o que fica mais evidente no seguinte trecho.

Chegamos a ficar por algum tempo - não posso dizer quanto - inteiramente calados. O rumor único e escasso era um roer de camundongo no gabinete, que me acordou daquela espécie de sonolência; quis falar dele, mas não achei modo. Conceição parecia estar devaneando. Subitamente, ouvi uma pancada na janela, do lado de fora, e uma voz que bradava: "Missa do galo! missa do galo!" (p. 85)

O silêncio toma conta do espaço, marcando ainda mais a distensão a que o conto vai chegando. Mais uma vez, é o espaço exterior que se intromete no interior. Dessa vez, é o som na janela que marca o fim do episódio central da narrativa. 


\begin{tabular}{|l|l|l|l|l|l|l|}
\hline InterteXto & Uberaba & UFTM & $\begin{array}{l}\text { v. 1 } \\
\text { n. } 2\end{array}$ & p. 62-81 & 2008 - jul. / dez. & ISSN 1981-0601 \\
\hline
\end{tabular}

E com o mesmo balanço do corpo, Conceição enfiou pelo corredor dentro, pisando mansinho. Saí à rua e achei o vizinho que esperava. Guiamos dali para a igreja. Durante a missa, a figura de Conceição interpôs-se mais de uma vez, entre mim e o padre; fique isto à conta dos meus dezessete anos. (p. 85)

Conceição se recolhe pela mesma espacialidade anteriormente percorrida. Há como que um fechar do episódio: ele se abre com a vinda da personagem e se fecha com sua ida, há um estiramento e um recolhimento.

Também, é a primeira vez que há mudança de espaço. Antes, as personagens só se movimentavam no espaço da casa. Agora, Nogueira atravessa esse espaço, indo para a igreja. Temos, portanto, dois espaços: o da rua e o da igreja. Note-se que o deslocamento feito no eixo da prospectividade, perto/longe, aqui/lá, entre a casa e a igreja não é descrito pelo narrador. A única frase que ilustra o caminho percorrido é "Guiamos dali para a igreja." Em seguida, a frase demonstra que o narrador já se encontra na igreja. Essa omissão é uma estratégia comuníssima utilizada pelos narradores de modo geral. Naturalmente, o narrador só irá se ater àquilo que é importante para a narrativa. Essa omissão dos espaços intermediários pode ser interpretada como um tropo. Vejamos o que diz Certeau (2003, p. 180) a esse respeito:

O assíndeto é supressão dos termos de ligação, conjunções e advérbios, numa frase ou entre frases. Do mesmo modo, na caminhada, seleciona e fragmenta o espaço percorrido; ela salta suas ligações e partes inteiras que omite.

Ou seja, à estratégia de omissão espacial perpetrada pelo narrador podemos chamar de assíndeto espacial. É o que ocorre no trecho acima.

Também, quando o Nogueira afirma que “...a figura de Conceição interpôs-se mais de uma vez, entre mim e o padre..." é interessante notar que temos aí uma relação entre o sagrado e o profano, o espaço da igreja é invadido pelas lembranças do que ocorrera no espaço da casa.

Na manhã seguinte, ao almoço, falei da missa do galo e da gente que estava na igreja sem excitar a curiosidade de Conceição. Durante o dia, achei-a como sempre, natural, 


\begin{tabular}{|l|l|l|l|l|l|l|}
\hline InterteXto & Uberaba & UFTM & $\begin{array}{l}\text { v. 1 } \\
\text { n. } 2\end{array}$ & p. 62-81 & 2008 - jul. / dez. & ISSN 1981-0601 \\
\hline
\end{tabular}

benigna, sem nada que fizesse lembrar a conversação da véspera. Pelo ano-bom fui para Mangaratiba. Quando tornei ao Rio de Janeiro, em março, o escrivão tinha morrido de apoplexia. Conceição morava no Engenho Novo, mas nem a visitei nem a encontrei. Ouvi mais tarde que casara com o escrevente juramentado do marido. (p. 85)

Esse trecho encerra o conto. O narrador afirma o desinteresse de Conceição pelo que houvera na noite anterior. No entanto, o final deixa uma suspeição, mais uma. Quando o narrador afirma "Ouvi mais tarde..." quando seria realmente esse mais tarde? Seria logo em seguida ao seu retorno ao Rio? Se sim, talvez isso seja um forte índice de que Conceição era adúltera. Pois entre a ida em janeiro e a volta em março só se passaram três meses no máximo! Isso significaria que Conceição não só perdera o marido, mas já casara novamente em tão pouco tempo! E ainda se casa com alguém muito próximo da família e que, certamente, freqüentava a casa. No entanto, esse "Ouvi mais tarde..." pode significa vários meses então a inferência de mulher adúltera não se justifica. Enfim, trata-se de um conto com desfecho enigmático. Ao final da leitura, aquela dúvida do narrador também se transfere subrepticiamente para o leitor virtual. Essa estratégia de dissimulação contribui enormemente para a eficácia estética do conto.

\section{Conclusão}

Nesse conto de Machado, há três cenários: a casa, a rua e a igreja. No entanto, é no cenário da casa em que transcorre a cena principal do conto. Seguindo a sugestão de Massaud Moisés, poderíamos dizer que o espaço da casa é um espaço com drama, enquanto os outros dois são espaços sem drama.

Essa espacialidade está intrinsecamente ligada aos vários efeitos de sentido que o texto produz. Essa imbricação entre percurso espacial e percurso temático é um dos pontos que fazem desse texto um conto antológico. 


\begin{tabular}{|l|l|l|l|l|l|l|}
\hline InterteXto & Uberaba & UFTM & $\begin{array}{l}\text { v. 1 } \\
\text { n. } 2\end{array}$ & p. 62-81 & 2008 - jul. / dez. & ISSN 1981-0601 \\
\hline
\end{tabular}

Tanto é assim que à tríade espacial correspondem também outras tríades: Meneses, Conceição e a amante de Meneses; Conceição, Nogueira e Meneses; Conceição, Meneses e o escrivão juramentado de Meneses; há ainda a menção às três chaves da porta. Naquela noite, uma ficava com o Meneses, outra com Nogueira e outra na própria casa. Como se não bastasse, Nogueira lê Os três mosqueteiros. Enfim, parece que a figura espacial do triângulo é a que rege todo o conto, simbólica e estruturalmente.

Do ponto de vista simbólico, percebemos que as personagens estão envolvidas em um triângulo amoroso explícito ou implícito. Trata-se portanto de uma relação complicada entre as personagens como se percebe mais claramente nas relações entre Meneses e sua esposa.

Do ponto de vista estrutural, percebemos que a tríade é a base de todo o texto, é a partir desse jogo triádico que o conto se desenrola, as incertezas vão aparecendo e os efeitos de sentido vão sendo construídos. Assim como o número três representa algo ainda não harmônico, sem pares, assim também o conto não se fecha como num círculo, mas se apresenta como um triângulo cujas pontas miram para vários lados, vários ângulos.

\section{Referências}

ASSIS, Machado. Missa do galo In Contos. p. 81-85. São Paulo: Ática, 1983.

BORGES FILHO, Ozíris. Espaço e literatura: introdução à topoanálise. Franca: Ribeirão gráfica editora, 2007a. . O espaço da narração e o espaço da narrativa. Estudos Lingüísticos (São Paulo), v. 37, p. 341-347, 2007b.

CERTEAU, Michel de. A invenção do cotidiano. 1. Artes de fazer. $9^{a}$. ed.

Petrópolis: vozes, 2003.

REIS, Carlos \& LOPES, Ana Cristina M. Dicionário de teoria da narrativa. São Paulo: Ática, 1988. 